\title{
Socio Economic Status and its Relation to Academic Achievement of Higher Secondary School Students
}

\author{
Farkhanda Ahmar*, Dr. Ehtesham Anwar** \\ *Research Scholar, Faculty of Education, Integral University, Lucknow (India) \\ **Associate Professor, Faculty of Education, Integral University, Lucknow (India)
}

\begin{abstract}
This study examined the effects of gender and socio-economic status on academic achievement of higher secondary school students of Lucknow city. The sample consists of 102 males and 98 females in age range of 15 to 19 from five higher secondary schools of Lucknow city Uttar Pradesh (India).Socio economic status scale developed by R.L.Bharadwaj (2005) was used for data collection, while the total mark obtained by the students in the previous class i.e. standard $X$ was used as an achievement criteria. Mean(M),Standard Deviation(S.D),Standard Error of the mean(S.E.M),t-test were used. This study shows that gender does not influence the achievement in science at higher secondary school (Standard-XI) level. Also the result of this study showed the difference between high and low socio-economic status groups. It is found that the academic achievement was influenced by the socio-economic status and those who belonged to high socio-economic status showed better performance. Based on these findings some recommendation was given with great implication for both practice and further studies.
\end{abstract}

Keywords: Academic Achievement, Gender, Higher Secondary School, Socio-Economic Status

\section{Introduction}

Human life, which is the best creation of god, has got two aspects: The biological and sociological or cultural. While the former is maintained and transmitted by food and reproduction, the latter is preserved and transmitted by education. It is through education that he promotes his intelligence and adds his knowledge with which he can move the world for good and for evil according to his wishes. Education in fact, is one of the major "life processes" of the human beings "just as there are certain indispensable vital processes of life in a biological sense. So education may be considered a vital process in a social science. Education is indispensable to normal living, without education the individual would be unqualified for group life (Safaya, 1963).

Academic Achievement assumes primary importance in the context of an education system aimed at progressive scholastic development of the child and human resources development at the macro level. The scientific rearing and education of a child is monitored on the basis of his academic achievement. Academic achievement is the core of the wider term i.e. educational growth. The importance of academic achievement in one's life cannot be over emphasized. It acts as an emotional tonic. Sound academic records are the pillars on which the entire future personality stands. Academic achievement have always been the centre of educational research and despite varied definitions about the aims of education, the academic development of the child continue to be the primary and most important goal of education . Life in general and for a student in particular has become highly competitive. Today there is no place for a mediocre student. There is limited room at the top that too only for the best. The importance of scholastic and academic achievement has raised important questions for educational researchers. What factors promote achievement in students? How far do the different factors contribute towards academic achievement? (Ramaswamy, 1990). In this context, the role of socioeconomic status cannot be denied as it has a great effect on personality, learning and development of the individual and his academic achievement

It is generally believed that children from high and middle socio-economic status parents are better exposed to a learning environment at home because of provision and availability of extra learning facilities. This idea is supported by Becker \& Tomes (1979) when they assert that it has become well recognized that wealthy and well-educated parents ensure their children's future earning by providing them a favorable learning environment, better education, and good jobs. In contrast to this belief, children from low socio-economic status parents do not have access to extra learning facilities; hence, the opportunity to get to the top of their educational ladder may not be very easy. Drummond \& Stipek (2004) while discussing their "Low-income Parents' beliefs about their role in children's academic learning" mentioned that a few of these parents indicated that their responsibilities were limited to meeting children's basic and social emotional needs, such as providing clothing, emotional support, and socializing manners. So these parents' shortsightedness toward their responsibilities in the educational processes of their children and scarcity of fund to intensify such processes 
could be a challenge to their children's success. The present study makes a humble endeavor to investigate the influence of student's socio economic status on the academic achievement of higher secondary school students.

\section{Conceptual Framework}

At a time of lively appraisal of educational development, when many changes are being witnessed in organization, curricular and teaching techniques, it is pertinent to seek systematic and up to date information on the significant correlates of achievement. It is appropriate, in this context, to consider at once the factors affecting academic achievement such as the student's socio-economic background

Chopra (1969) of Lucknow University studied the relationship between socio-economic background and achievement. It was found that higher socio- economic group students were significantly higher than those of the students from the middle and lower socio- economic group. This study revealed that there is positive relationship between socio- economic background and achievement in English, mathematics and science. Goswami (1982) found that in both urban and rural areas, the upper socio- economic status group has done significantly better than the lower socio-economic group in the achievement tests of science, languages and humanities. Rothman's (2003) analysis revealed that within the same school, a student who comes from a higher socio-economic group will achieve better test results than a student from a lower socio-economic group. In Britain, according to a recent report by the United Kingdom Government's Social Exclusion Unit (2004), a child born into the bottom social class is still more likely to leave school with no qualifications, to live in relative poverty and to die younger than their peers born into the professional classes. Sirin (2005,) explains, “...methodological characteristics, such as the type of SES measure, and student characteristics, such as student's grade, minority status, and school location, moderated the magnitude of the relationship between SES and academic achievement." The relationship is still clear and strong enough, however, to permit statements such as the following:

"Socio-economic status differences in children's reading and educational outcomes are ubiquitous, stubbornly persistent and well documented" (Aikens and Barbarin, 2008). The relationship between SES and academic achievement is due to a complex interaction of a number of variables, it appears to be generally accepted that SES impacts to a considerable extent on various aspects of students' learning experiences.

Meeuwisse, Severiens and Born (2010) examined the interaction of multiple variables in students' decisions to withdraw from higher education. They support the general theme that emerges in all of the studies reviewed herein: The interplay of variables that characterizes the investigation of SES and aspects of students' behavior, choices and outcomes is tremendously complex.

The present study was aimed at achieving the following objectives

i) To ascertain academic achievement among male and female students at higher secondary school level.

ii) To ascertain academic achievement among high socio-economic status male and female students at higher secondary school level.

iii) To ascertain academic achievement among low socio-economic status male and female students at higher secondary school level.

iv) To ascertain academic achievement among high and low socio-economic status male students at higher secondary school level.

v) To ascertain academic achievement among high and low socio-economic status female students at higher secondary school level.

\section{Hypotheses of the study}

i) There will be no significant difference between the academic achievement among male and female students at higher secondary school level.

ii) There will be no significant difference between academic achievement among high socio-economic status male and female students at higher secondary school level.

iii) There will be no significant difference between academic achievement among low socio-economic status male and female students at higher secondary school level.

iv) There will be no significant difference between academic achievements among high and low socioeconomic status male students at higher secondary school level.

v) There will be no significant difference between academic achievements in science among high and low socio-economic status female students at higher secondary school level.

\section{Justification of the study}

One of the most important outcomes of any educational set up is achievement of the students. Depending on the level of achievement individuals are characterized as high achievers, average achievers and low achievers. Many studies indicate that the academic achievement is dependent on variables like school/college set-up and its organization, socio-economic status of students, educational aspiration, well 
adjusted behavior etc. Beside these the personal characters, vocational aspirations, creativity intelligence, attitude, values, etc also influence it. But socio-economic status plays a major role. The division of society in to different classes and association of parents with a certain class and its linked with the education of their children is an all important feature of our society. The home, as is universally accepted, is the first school of child. As such, a suitable home environment is most conducive to the spread of education among its young members. Parent's socio economic status is an important factor in shaping their attitude towards encouragement or neglect of education of children. Students belonging to high socio economic status could get easily all the necessary things which they require for their high achievement.

To realize the democratic ideal of equalizing educational opportunity, it's necessary to estimate the extent to which progress in education .i.e academic achievement at higher secondary school level in Lucknow is being influenced by the socio-Economic variables. The present investigation, therefore was conducted to fulfill this need and aimed at to explore the relationship of the socio-economic variables with academic achievement It was assumed that the conclusions drawn on the basis of the study regarding the relationship between the variables and their effect on academic achievement might provide necessary guide line for improving the academic achievement of higher secondary school students.

\section{Methodology}

The method adopted for this study was descriptive and statistical in nature. The sample consists of 200 students selected from five different colleges of Lucknow, Uttar Pradesh, India. Out of 200 students 102 were males and 98 were females in age range of 15 to 19 from five higher secondary schools of Lucknow city Uttar Pradesh (India).In Lucknow, there are various separate secondary schools for the boys and the girls. To have a comparative study of the boys and the girls, the sample was drawn from both the boys and the girl's institutions. Stratified random sampling technique was applied for selection of the students for the sample.

\section{Name of the Schools}

1. Islamia boy's Inter College

2. Rajkiya Balika girl's Inter College.

3. St. Mary public Inter College.

4. St. Agnes Loreto day Convent school.

5. Center public inter college
List of the schools

Number of the students

47

39

49

35

30

IV. Tools used

In the present study standardized tool (socio economic status scale) has used. Standardization is referred to proper item selection and high reliability, validity and usability. In the present study, following standardized tools were used:-

1. Socio-Economic Status (SES) - a scale developed by R.L.Bharadwaj (2005)

2. Academic achievement- the academic achievement of students was recorded from school record.

\section{Results and Analysis}

Data analysis is performed on computer with SPSS 17 software package. When data was analyzed to make a comparative study of the academic achievement of male and female students (Table 1) the result shows there is no significant difference between academic achievement of males and females ( $\mathrm{df}=198 \mathrm{t}=0.364)$.

Table 1

Significance of the Difference Between Means of Academic Achievement of Male and Female Students.

\begin{tabular}{|l|l|l|l|l|l|}
\hline Gender & $\mathbf{N}$ & Mean & $\begin{array}{l}\text { Standard } \\
\text { Deviation }\end{array}$ & Standard Error Mean & t-value \\
\hline Male & 102 & 59.4216 & 15.64801 & 1.54938 & 0.364 \\
\hline Female & 98 & 58.6531 & 14.10352 & 1.42467 & $\mathrm{df}=198$ \\
\hline
\end{tabular}

The total numbers of male and female student were $102 \& 98$ respectively as indicated by the table 1 . The mean of achievement score of male students is 59.421 and the mean score of female students is 58.653. The S.D of the achievement of male students is 15.648 and the S.D of the achievement of female students is 14.103.S.E.Mean of the achievement score of male and female students are 1.549 and 1.424 respectively. The statistically calculated t-value is 0.364 which is not significant at 0.05 level with $198 \mathrm{df}$. Thus, null hypothesis which states that there is no significant difference between the academic achievement of the male and female students shall 
be accepted. It indicates that gender does not affect academic achievement. The results have also been depicted in the figure 1 given below.

\section{Figure 1 Academic Achievement Scores of Male and Female Students}

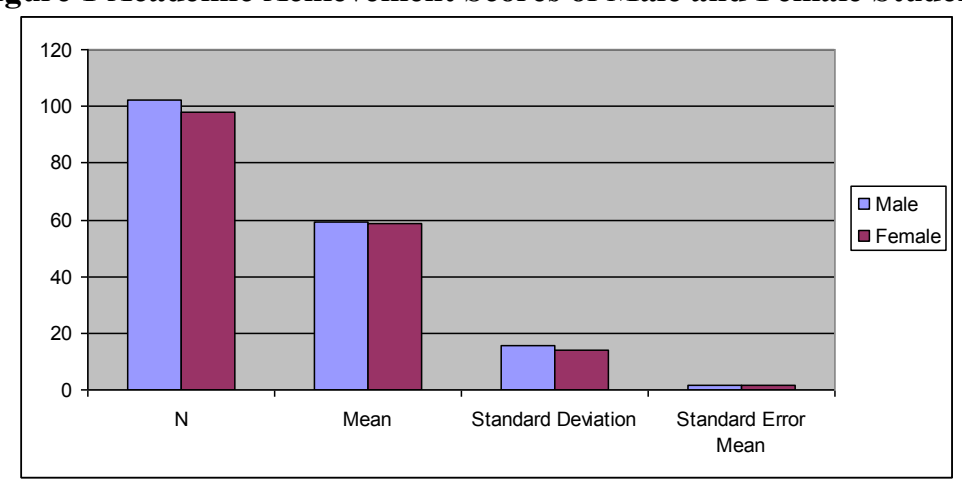

Table 2

Significance of the difference between means of Academic Achievement of Male and Female Students of High Socio Economic Status

\begin{tabular}{|l|l|l|l|l|l|}
\hline Gender & N & Mean & $\begin{array}{l}\text { Standard } \\
\text { Deviation }\end{array}$ & Standard Error Mean & t-value \\
\hline Male & 43 & 72.4419 & 13.01703 & 1.98508 & 0.004 \\
\hline Female & 37 & 72.4324 & 9.81931 & 1.61429 & $\mathrm{df}=78$ \\
\hline
\end{tabular}

The above table shows that there were 43 male students and 37 female students of high socio economic status. The mean of achievement of male (high SES) is 72.441 and the mean of achievement of female (high SES) is 72.432. The standard deviation of achievement of male students is 13.017 and the standard deviation of female students is 9.819. The standard error mean of achievement score of male students is 1.985 and that of female students is 1.614 . The $t$-value is .004 which is not significant at 0.05 level of significance. So the null hypothesis which states that there will be no significant difference between academic achievement of male and female students of high socio economic status shall be accepted. It indicates that academic achievement of male and female students of high socio-economic status does not significantly differ. Results have been depicted in the figure 2 given below.

Figure 2 Achievement scores of Male and Female of High Socio Economic Status.

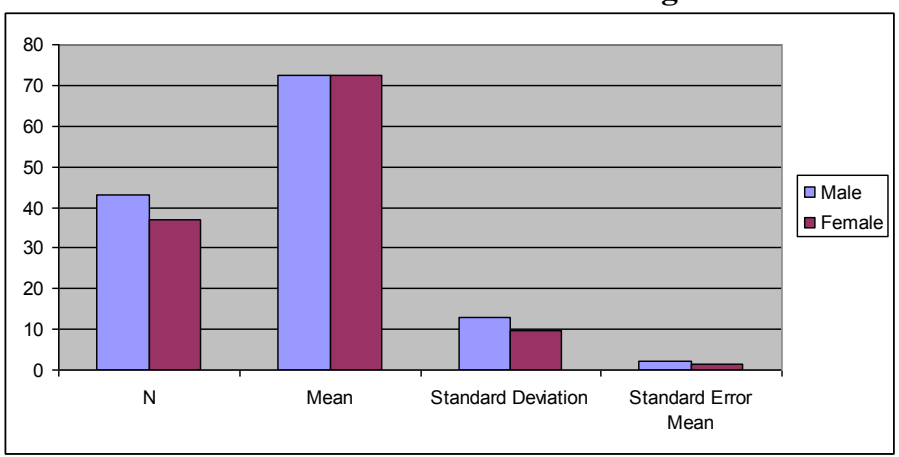

Table 3

Significance of the difference between Means of Academic Achievement of Male and Female Students of Low Socio Economic Status.

\begin{tabular}{|l|l|l|l|l|l|}
\hline & $\mathbf{N}$ & Mean & $\begin{array}{l}\text { Standard } \\
\text { Deviation }\end{array}$ & $\begin{array}{l}\text { Standard Error } \\
\text { Mean }\end{array}$ & t-value \\
\hline Male & $\mathbf{3 7}$ & 47.9459 & 9.92736 & 1.63205 & 0.932 \\
\hline Female & $\mathbf{2 6}$ & 50.3462 & 10.26817 & 2.01375 & $\mathrm{df}=61$ \\
\hline
\end{tabular}


The above table shows that there were 37 male students and 26 female students of low socio economic status. The mean of achievement of male (low SES.) is 47.945 and the mean of achievement of female (low SES) is 50.346 .The standard deviation of achievement of male students is 9.927 and the standard deviation of female students is 10.268 . The standard error mean of achievement score of male students is 1.632 and that of female students is 2.013. The t-value is 0.932 at 61 degree of freedom which is not significant at 0.05 level of significance. So the null hypothesis which states that there will be no significant difference between achievement of science of male and female of low socio economic status shall be accepted. It indicates that achievement in science of male and female students of low socio-economic status does not significantly differ. The results have also been depicted in the figure 3 below.

\section{Figure 3- Academic Achievement of Male and Female Students of Low Socio Economic Status.}

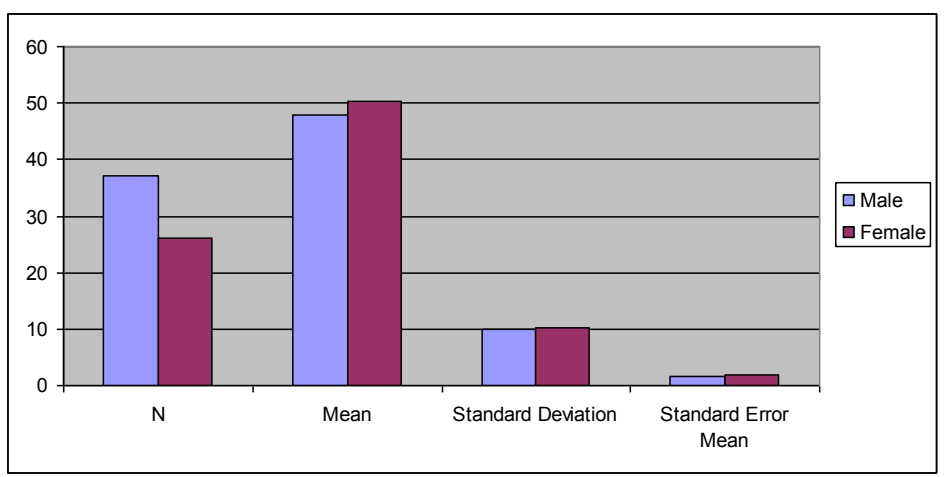

Table-4

Significance of the Difference between the Means of Academic Achievement of Male Students of High and Low Socio Economic Status.

\begin{tabular}{|l|l|l|l|l|l|}
\hline & $\mathbf{N}$ & Mean & $\begin{array}{l}\text { Standard } \\
\text { Deviation }\end{array}$ & Standard Error Mean & t-value \\
\hline High SES Male & $\mathbf{4 3}$ & 67.1395 & 15.13838 & 2.30858 & 6.586 \\
\hline Low SES Male & $\mathbf{3 7}$ & 47.9459 & 9.92736 & 1.63205 & $\mathrm{df}=78$ \\
\hline
\end{tabular}

In the above table there were 43 male students of high socio economic status and 37 male students of low socio economic status. The mean of the achievement scores of male students of high socio economic status is 67.138 and the mean of achievement scores of male students of low SES is 47.945.It shows that male students of high socio economic status achieve more score than that of low socio economic status students. The standard deviation of male students of high socio economic status is 15.138 and the standard deviation of male students of low socio economic status is 9.927.The S.E.M. of male students of high SES is 2.308 and the S.E.M. of male students of low SES is 1.632. The t-value is 6.586 at 78 degree of freedom which is significant at 0.05 level of significance. So the null hypothesis which states that there will be no significant difference between academic achievement of male students of high SES and male students of low SES shall be rejected. It interprets that socio economic status of male students affects their academic achievement. The results have been depicted in the figure 4 given below.

Figure 4- Academic Achievement of Male Students of High and Low Socio Economic Status.

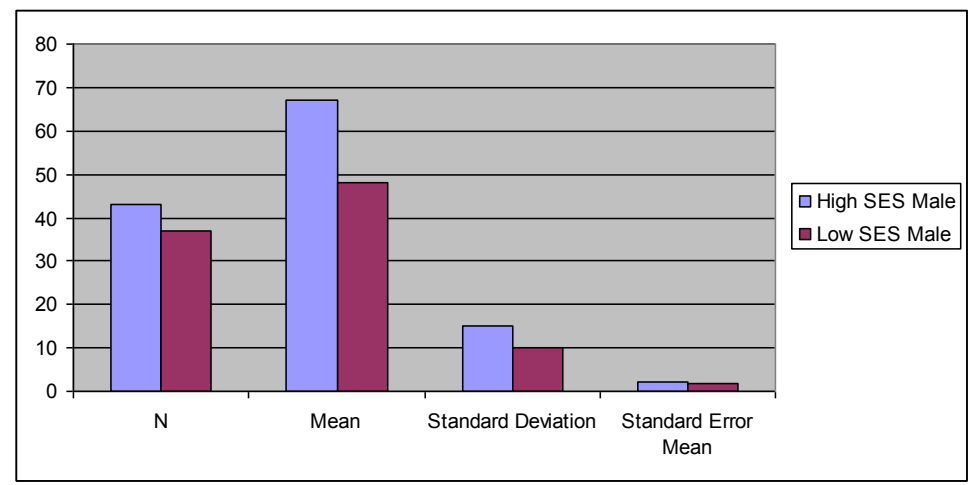


Table 5

Significance of the Difference between the Means of Academic Achievement of Female Students of High and Low Socio Economic Status.

\begin{tabular}{|l|l|l|l|l|l|}
\hline & N & Mean & $\begin{array}{l}\text { Standard } \\
\text { Deviation }\end{array}$ & $\begin{array}{l}\text { Standard Error } \\
\text { Mean }\end{array}$ & t-value \\
\hline High SES Female & 37 & 69.2703 & 8.64307 & 1.42091 & 7.915 \\
\hline Low SES Female & 26 & 50.3462 & 10.26817 & 2.01375 & $\mathrm{df}=61$ \\
\hline
\end{tabular}

In the above table there were 37 female students of high socio economic status and 26 female students of low socio economic status. The mean of the achievement scores of female students of high socio economic status is 69.270 and the mean of achievement scores of female students is 50.346.It shows that female students of high socio economic status achieve more than that of low socio economic status. The standard deviation of female students of high socio economic status is 8.643 and the standard deviation of female students of low socio economic status is 10.268. The S.E.M. of female students of high SES is 1.420 and the S.E.M. of female students of low SES is 2.013. The t-value is 7.915 at 61 degree of freedom which is significant at 0.05 level of significance. So the null hypothesis which states that there will be no significant difference between academic achievement of female students of high SES and female students of low SES shall be rejected. It interprets that socio economic status of female students affects their academic achievement. The results have also been depicted in the figure 5 given below.

Figure 5. Academic Achievement of Female Students of High and Low Socio Economic Status.

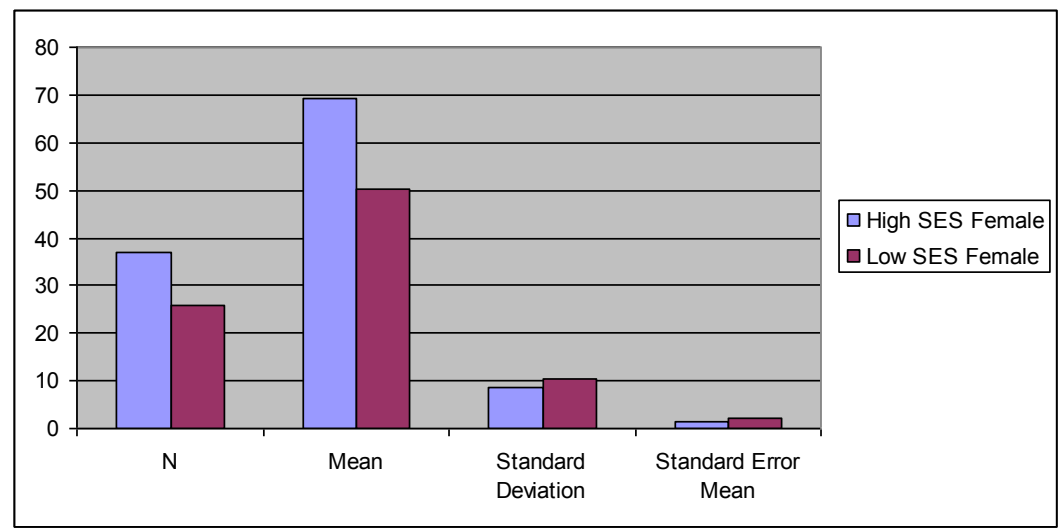

\section{Discussion}

Application of t-test shows that the mean scores of students at higher secondary school do not differ significantly gender-wise, i.e. when the academic achievement of students of males and females were compared they did not differ significantly. This study shows that gender does not influence the academic achievement of higher secondary school students. The finding of this study is in line with findings of previous studies. Taj and Bhargava (1999) carried out a similar study on the socio psychological correlates of academic performance and found that gender does not influence academic achievement.

When the data was analyzed on the basis of socio economic status to see the difference between the academic achievements of high and low socio-economic status of male students at higher secondary school level the findings were that significant difference were there. On the basis of this result we can say that males having higher socio-economic status score high academic achievement in comparison of males having low socioeconomic status that is because their parents provided all the necessary facilities regarding their children education, health and understand their problems related to adolescent period which affect their academic achievement. This result is supported previous studies such as Kaur (1971) who conducted a study on a sample of 60 boys of class IX in Patiala city and observed a highly significant correction between socio-economic status $\&$ scholastic achievement of the boys of higher secondary school. Furthermore Havighrust (1964) concluded a study on high school boys in six different schools in the eastern united stated that the grades awarded to their social status. He found that the lower status boys also get more direct form of punishment. The teacher's reports of counseling with parents are also summarized. According to the author's statements most of the counseling about discipline was with parents of lower status boys who are influenced adversely by their peer group who are from similar socio economic status and these factors affect their academic achievement. 
When the data were analyzed to see the difference between academic achievements of female students belonging to high and low socio- economic status, there was significant difference in academic achievement of female students of high and low socio economic status. This result is supported by many previous studies such as Khan (1991) who conducted study on socio economic status and academic achievement, Chopra (1969 and 1982) Frempong (2000) and White (1982). In the studies of White (1982) and Srivastava (1974) this point of view is strongly supported as they reported Socio economic status to be strong predictor of academic achievement of girls. They found that girls belonging to low socio economic status are generally busy in their household work with her mother in very early stage of their life and they don't have much time and facilities which require for scoring good academic score. Rothman's (2003) analysis revealed that within the same school, a girl who comes from a higher socio-economic group will achieve better test results than a girl from a lower socio-economic group. Barger and Hall (1965) have shown that the high socio-economic status of school students was conducive to high academic achievement. Also in his study Menon (1973) investigated and found out the difference between high and low socio-economic status groups. He concluded that the academic achievement was influenced by the socio-economic status accordingly, those who belonged to high socioeconomic status showed better performance.

\section{Limitation of the study}

It is not possible in a single research study to cover every aspect of variables associated with the problem under investigation. Although, the problem is very natural and is prevalent everywhere yet due to shortage of time and resources all the aspects variables could not be covered and the study is limited in several ways. It had to be determined in terms of population covered, sample selected, scope of variables studied and the scope of generalizability of finding and so on.

1. Due to the shortage of time and resources the study was carried out only on students of class XI although problem of achievement is common to elementary classes yet the focus of the study has been on the higher secondary stage only.

2. The phenomenon of achievement has been studied on in relation to gender and socio-economic status only

3. The scope of study covers only urban areas of Lucknow city of Uttar Pradesh One cannot generalize the finding of this study to all the schools of India due to number of differences in their conditions and circumstances.

4. It is desirable that the researcher reaches first hand or original sources for the study, but as access to some material was not possible materials taken from available secondary sources has been used.

5. Though the stratified random sampling is adapted for selection of samples at which extent it was practicable but due to some other factors like permission for administration of the tests and availability of schools made the researcher forced to adopt the purposive sampling as an alternative measure for the study.

\section{References}

[1] Becker and Tomes (1979), "An Equilibrium Theory of the Distribution of Income and Intergenerational Mobility." Journal of political economy, 87, 1153-1189

[2] Chopra (1964), "A study of Relationship of Socio-economic factors with environments of the students in the secondary schools". Doctoral dissertation, Lucknow University

[3] Drummond \& Stipek (2004), "Low Income Parent's Beliefs about Their Role in Children's Academic Learning." The Elementary School Journal Vol. 104, No-3, 197-213

[4] Frempong G, Willms D.(2000), "Can school quality compensate for socioeconomic disadvantage”? In: Willms D, editor. Vulnerable Children. Edmonton: University of Alberta Press; 2002. pp. 277-304.

[5] Goswami. R. (1982). "An Enquiry into Reading Interests of the Pupils of Standard VII to X in Relation to Intelligence”, SES and Academic Achievement. Doctoral Dissertation, M. S. University, Baroda.

[6] Khan and Jemberu (2002), "Influence of family Socio Economic Status on educational and occupational Aspirations of high and low achieving adolescents". J. Com. Guid. Res., 19(1): 113-118

[7] Kaur (1971), "A study of relationship of socio-economic status with the achievement of students in secondary school" PhD thesis in education pan university

[8] Menon (1973), "Performance of students of polytechnics in relation to their socio-economic status and aspiration level" PhD thesis in education

[9] Meeuwisse, Severiens and Born (2010), "Reasons from withdrawal from higher vocational education . A comparison of Ethnic minority and majority Non completers" Studies in higher education 35(1), 93-111. Lokan, Green wood and Cresswell, 2001, p, 151

[10] Rothman's (2003), "The changing influence of socio economic status on students academic achievement," recent evidence from Australia , Paper presented at the annual meeting of the American education Research Association, Chicago, April 2003

[11] Ramaswamy, R.(1990), “Study habits and Academic Achievement." Expt. Education., 18(10): $255-260$.

[12] R.Aikens and Barbarin, (2008), "Socio economic differences in reading trajectories, " The contribution of family , Neighborhood and school context, Journal of educational psychology , 10092), 235-251

[13] Robert J. Havighurst (1964)“The Chicago School Survey” The Phi Delta Kappan international, Vol. 46, No. 4, pp. 162-166.

[14] Safaya (1963), "Principles and Techniques of Education." Dhanpat Raj and Sons Com, New Delhi

[15] Sirin (2005), Socio-economic status and Academic achievement, " A meta analytical Review of educational Research, 75(3), 417453 
[16] Sukhendra Lal Chopra ( 1969), "Father occupation is the indicator of socio economic background" Journal of educational Research, vol. 6, No-10, pp -35-37"

[17] Srivastava (1974), "An investigation in to the factor related to under achievement" Doctoral dissertation, Patna University

[18] Taj, Haseen, Bhargava, \& Mahuh. (1999). "Social-Psychological Correlates of Academic Performance. "Asian Journal of Psychology and Education, 32 (7-8), 16-32.

[19] United Kingdom Government's Social Exclusion Unit (2004) “The impact of government policy on social exclusion among young people"www.socialexclusionunit.gov.uk.

[20] White, K.R (1982), “The relationship between socio-economic status and Academic Achievement," Psychological Bulletin, 91(3), 461-481. 